\title{
RUMUŃSKIE ROSZCZENIA TERYTORIALNE WOBEC BUŁGARII W DOBIE WOJEN BAŁKAŃSKICH
}

\author{
ELŻBIETA ZNAMIEROWSKA-RAKK
}

\begin{abstract}
Elżbieta Znamierowska-Rakk, Rumuńskie roszczenia terytorialne wobec Butgarii $w$ dobie wojen batkańskich (Romanian claims against Bulgaria during the period of the Balcan Wars).
\end{abstract}

Balcanica Posnaniensia. Acta et studia, XIX, Poznań 2012, Wydawnictwo Instytutu Historii UAM, pp. 287-295, ISBN 978-83-63-047-17-7, ISSN 0239-4278. Polish text with a summary in English.

Elżbieta Znamierowska-Rakk, Uniwersytet Warszawski, Studium Europy Wschodniej, Krakowskie Przedmieście 26/28, Warszawa.

Kwestia roszczeń terytorialnych Rumunii pod adresem Bułgarii w dziejach najnowszych, jak dotąd, nie została wystarczająco przebadana w historiografii polskiej. Jeżeli chodzi o okres wojen z lat 1912-1913 to trzeba stwierdzić, że na ogół badacze skupili się na analizie genezy, przebiegu i skutków tych wydarzeń w odniesieniu do państw sygnatariuszy sojuszu bałkańskiego - Serbii, Bułgarii, Czarnogóry i Grecji, zawartego w celu położenia kresu władztwu osmańskiemu na Bałkanach. Rumunia zaś bywa traktowana raczej marginalnie i to przeważnie dopiero w kontekście wojny międzysojuszniczej. Podczas gdy aneksja Dobrudży Południowej - obszaru pozostającego w granicach państwa bułgarskiego, dokonana przez Rumunów pod koniec II wojny bałkańskiej w 1913 r. może się jawić, jako swego rodzaju wbicie noża $\mathrm{w}$ plecy, niespodziewany akt wrogi wymierzony przeciwko południowemu sąsiadowi w ciężkim dla niego położeniu. Bo ówcześnie niemalże wszystkie bułgarskie siły zbrojne skoncentrowane były na froncie zachodnim, gdzie w dramatycznych zmaganiach z wojskami serbskimi, czarnogórskimi i greckimi były bliskie poniesienia klęski. Zabór bułgarskiej części Dobrudży może zatem sprawiać wrażenie wykorzystania przez armię rumuńską ad hoc okoliczności sprzyjających łatwemu, bezkrwawemu sięgnięciu po terytorium, usytuowanego tuż przy granicy rumuńsko-bułgarskiej, a co więcej, pozbawionego prawie elementarnej obrony wojskowej. Tymczasem, nie negując wpływu owej niezwykle dogodnej koniunktury, trzeba stwierdzić, że przyłączenie Dobrudży Południowej do państwa rumuńskiego stanowiło ukoronowanie ponad trzydziestoletnich aspiracji i konkretnych 
zabiegów dyplomatycznych, niestrudzenie podejmowanych przez koła rządzące w Bukareszcie.

Pretensje Rumunów do owej ziemi miały ścisły związek z traktatem berlińskim z 1878 r., kiedy to po wojnie wygranej przez Rosję z imperium osmańskim, mocarstwa europejskie ustanowiły nowy ład terytorialno-narodowościowy na Bałkanach. Zgodnie z postanowieniami owego traktatu Rumunia uzyskała pełną suwerenność państwową, lecz zarazem pozbawiano ją Besarabii - obszaru rdzennie rumuńskiego' Warto przypomnieć, że ziemia ta w 1812 r. została zaanektowana przez Rosję, ale po jej klęsce w wojnie krymskiej (lata 1853-1856) południowa część Besarabii powróciła do Rumunii². Niemniej skomplikowany układ sił na arenie europejskiej, ukonstytuowany po zakończeniu wielkiego kryzysu bałkańskiego (1875-1878), zadecydował o odebraniu Rumunii tego fragmentu prowincji besarabskiej na rzecz imperium rosyjskiego.

Wszakże w celu osłodzenia Rumunom przełknięcia tej gorzkiej pigułki przyznano im Dobrudżę Północną - obszar zamieszkany w znacznym procencie przez ludność bułgarską, a przy tym o wiele mniej cenny ekonomicznie, ile strategicznie i psychologicznie w porównaniu z Besarabią ${ }^{3}$. Było to zatem dość wątpliwe wyrównanie, gdyż nie tylko nie równoważyło utraconych korzyści z powodu odcięcia prowincji besarabskiej, ale także skutkowało potencjalnym konfliktem z Bułgarią. Stąd czynniki rządzące w Bukareszcie początkowo usiłowały zmienić lub udaremnić realizację owej niekorzystnej decyzji. Ostatecznie jednak, wobec bezowocności swych zabiegów, zmuszone były pogodzić się z dyktatem mocarstw. Niemniej z czasem Dobrudża Północna nabrała w oczach Rumunów ważnego znaczenia polityczno-strategicznego, jako obszar oddzielający słowiańską Rosję od słowiańskiej Bułgarii, co miało udaremnić ekspansję imperium rosyjskiego na Cieśniny Czarnomorskie, zagrażającą interesom Rumunii ${ }^{4}$. W tym stanie rzeczy rząd rumuński zdecydował utrwalić władanie prowincją dobrudżańska, przeciwdziałając irredencie tamtejszych Bułgarów oraz zabezpieczając tę ziemię przed spodziewanymi zakusami ze strony państwa bułgarskiego. Przede wszystkim starano się zmienić jej oblicze etniczne drogą wzmożonej rumunizacji ${ }^{5}$, a jednocześnie zabiegano o odpowiednie wzmocnienie granicy rumuńsko-bułgarskiej. Największy niepokój Bukaresztu budziły twierdze bułgarskie, usytuowane wokół miasta Silistra w Dobrudży Południowej, stanowiące potencjal-

1 Ot San Stefano do Pariž 1878-1947. Najvažnite dogovori za B"lgariâ, Sofiâ 2009, s. 41-56; B. Kesâkov, Prinos k"m diplomatičeskata istoriâ na B"lgariâ 1878-1925, t. I, Sofiâ 1926, s.1-16; D.P. Hupchick, The Balkans. From Constantinopole to Communism, Polgrave Macmilan 2004, s. 265266.

2 A. Kastory, Rozbiór Rumunii w 1940 roku, Warszawa 2002, s. 14-15.

${ }^{3}$ S. Dimitrov, N. Zečev, V. Tošev, Istorija na Dobrudža, t. 3, Sofiâ 1988, s. 282-286.

${ }^{4}$ G. Zbuchea, România şi Râzboaiele Balcanice 1912-1913. Pagini de istorie Sud-Est Europeanâ, Bucureşti 1999, s. 24-25.

${ }^{5} \mathrm{P}$. Todorov, Ideini tečeniâ i borbi v dobrudžanskoto nocionalnoosvoboditelno dviženie do $1919 \mathrm{~g}$. w: B"lgarskiât nocionalen v"pros sled Berlinskiâ kongres (do socialističeskata revoluciâ), Sofiâ 1986, s. 117 i nn.; szerzej: V. Tonev, Dobrudža po vreme na osvoboditelna vojna, „Istoričeski pregled” [Sofiâ] 1977, nr 5-6 s. 162-168. 
ną groźbę interwencji militarnej Bułgarii w Dobrudży Północnej. W rezultacie władze rumuńskie, pragnąc zawładnąć tym miastem wraz z jego okolicami, podejmowały działania spowalniające prace międzynarodowej komisji, powołanej przez traktat berliński do wyznaczenia linii granicznej pomiędzy Rumunią a Bułgarią. Równolegle do zabiegów Rumunów na płaszczyźnie dyplomatycznej doszło też do rumuńskich akcji wojskowych w pobliżu Silistry, skutkujących zajęciem okolicznych terenów. Aby przekonać przedstawicieli mocarstw europejskich o konieczności władania Silistrą, władze rumuńskie eksponowały nie tylko rzeczywiste motywy strategiczne, lecz również gospodarcze. Argumentowano, że zajęte przez wojsko okolice i samo miasto są niezbędne dla Rumunii w celu zbudowania mostu w dolnym biegu Dunaju, służącego zarówno komunikacji wewnętrznej, jak i międzynarodowej ${ }^{6}$.

Wszelako granica pomiędzy obu sąsiednimi państwami, ustalona ostatecznie w drugiej połowie lat 80. XIX w. przez międzynarodowe gremium, nie uwzględniła aspiracji Bukaresztu. Nie wpłynęło to wszakże na zaprzestanie wysiłków Rumunów w dalszych latach w kierunku jej rektyfikacji. A trzeba stwierdzić, że pod koniec XIX i na początku XX w. rachuby rumuńskich kół rządzących na zmianę dobrudżańskiej granicy nie były pozbawione szans powodzenia. Ukształtowana, bowiem, wówczas dychotomiczna konfiguracja mocarstw na arenie europejskiej sprzyjała rewizjonistycznym i ekspansjonistycznym tendencjom w polityce państw kontynentu. Funkcjonowanie wszak dwóch przeciwstawnych bloków polityczno-wojskowych - Trójprzymierza i Trójporozumienia, zabiegających o utrzymanie lub włączenie Rumunii w orbitę swych wpływów pozwalało przywódcom tego kraju stosować taktykę lawirowania. Niemniej jednak główne roszczenia terytorialne Bukaresztu Transylwania i Besarabia jawily się, jako nader problematyczne, gdyż aspiracje do tego pierwszego terytorium wykluczałyby pozostawanie Rumunii w sojuszu Niemiec, Austro-Węgier i Włoch, zaś żądania zwrotu tego ostatniego - uniemożliwiałyby zbliżenie do ugrupowania Francji, Rosji i Wielkiej Brytanii. W tej sytuacji zaspokojenie owych pretensji zależało od wybuchu konfliktu wojennego między mocarstwami i od przyjęcia przez rumuński rząd orientacji na ten blok militarno-polityczny, który by zwyciężył.

Niemniej w przypadku konsekwentnych zabiegów Rumunów o przyłączenie mniejszej lub większej części Dobrudży Południowej tego rodzaju ograniczenia nie występowały; rumuńskie pretensje, bowiem, pod adresem Bułgarii nie kolidowały z interesami mocarstw. Wysiłki Rumunii w tym kierunku nasiliły się, gdy coraz wyraźniej ujawniał się priorytetowy cel bułgarskiej polityki zagranicznej, zmierzającej do aneksji Macedonii i Tracji, co zaznaczyło się zwłaszcza po proklamowaniu przez Bułgarię w 1908 r. pełnej suwerenności państwowej, jako cesarstwa. Perspektywa taka zrodziła obawy Bukaresztu przed wzmocnieniem pozycji Bułgarii na Bałkanach, potencjalnie skutkującym hegemonią tego państwa w regionie, a także siłowym ode-

\footnotetext{
${ }^{6}$ Szerzej: V. Arabov, Razmânata na Dobrudža s Besarabiâ. Otkaz"t na rum"nite ot Dobrudža. Učastieto na Rum "niâ v Rusko-turskata vojna ot 1877-1878, Sofiâ 1939; Ż. Popov, B "lgarite v Severna Dobrudža 1878-1913, Sofiâ 1991.
} 
braniem Dobrudży Północnej`. Toteż obok dotychczasowego, względnie skromnego, żądania rewizji granicy rumuńsko-bułgarskiej, ustalonej niekorzystnie w opinii kół rządzących w Rumunii, przywódcy tego kraju podnieśli konieczność przywrócenia równowagi politycznej $\mathrm{w}$ regionie bałkańskim, jeśli zostanie ona naruszona $\mathrm{w}$ wyniku zjednoczenia $w$ granicach Bułgarii ziem macedońskich i trackich. Konkretnie zaś domagano się od Bułgarów stosownej rekompensaty terytorialnej. W końcu XIX w. i na początku XX w. Rumunia określiła swoje kompensacyjne aspiracje do całego terytorium Dobrudży Południowej, a nawet pewnej części ziem przyległych. Rumuńskie pretensje terytorialne stanowiły czworokąt, wyznaczony przez takie miasta, jak Szumen - Ruse - Silistra - Warna ${ }^{8}$. W celu stosownego uzasadnienia i nadania większego ciężaru gatunkowego żądaniom tak rozległego obszaru państwa bułgarskiego władze w Bukareszcie zaangażowały się w obronę praw Kucowołochów (zwanych też Arumunami), zamieszkujących ziemie macedońskie, do których pretendowała Sofia. Akcentowano przy tym kwestię spodziewanej emigracji ludności kucowołoskiej z Macedonii do Rumunii oraz wynagrodzeń za pozostawione przez nią nieruchomości w ojczystych stronach, gdy zapanują tam rządy Bułgarów9.

Realizacja pretensji terytorialnych Rumunii przede wszystkim zależała od treści stosunków bułgarsko-tureckich, albowiem Bułgaria w spodziewanym konflikcie wojennym z Turcją o wiele trudniej mogłaby przeciwstawić się roszczeniom swego północnego sąsiada. Śledząc bacznie stan relacji na linii Sofia-Istambuł władze w Bukareszcie rozpatrywały korzyści, płynące z rumuńskiej bezstronności w razie wojny Bułgarii z imperium osmańskim. W rezultacie tych deliberacji zdecydowano, że Rumunia w tym konflikcie nie będzie deklarowała neutralności expressis verbis, lecz da Bułgarom niedwuznacznie do zrozumienia, iż może pozostać neutralną za cenę odpowiedniego wynagrodzenia. Nie precyzowano wszakże rozmiarów owej rekompensaty, ponieważ jej wielkość determinowały trudne do przewidzenia czynniki. Warto podkreślić, że różne warianty rumuńskich pretensji terytorialnych wobec Bułgarii dostosowywane były do zmieniających się możliwości, jakie stwarzała pozycja takiego czy innego mocarstwa, sprzymierzonego z jednym z dwóch rywalizujących ze sobą bloków polityczno-militarnych. Lecz władze w Bukareszcie zdawały sobie sprawę, że każde z mocarstw było gotowe poprzeć tylko takie modyfikacje na mapie Bałkanów, które odpowiadałyby jego interesom. Istotną rolę w precyzowaniu żądań rumuńskich odgrywało także położenie międzynarodowe i wewnętrzne oraz potencjał militarny dwóch bezpośrednio zainteresowanych państw: Rumunii i Bułgarii.

\footnotetext{
${ }^{7}$ M. Tanty, Bałkany w XX wieku. Dzieje polityczne, Warszawa 2003, s. 54; H. Batowski, Państwa batkańskie 1800-1923. Zarys historii dyplomatycznej i rozwoju terytorialnego, Kraków 1938, s. 203$-204$.

${ }^{8}$ R. W. Seton-Watson, A History of the Rumanians from Roman Times to the Completion of Unity, Cambridge 1934, s. 384, 436 za: A Kuzmanova, Rum"nskite teritorialni pretencii za Užna Dobrudža I Bukureškiât dogovor w: Bukureškiât dogovor I s"dbata na Užna Dobrudža, Dobrič 1994, s. 11.

${ }^{9}$ D. P. Hupchick, op. cit. s.301; szerzej: Ż. Popov, Rum"nskata propaganda v Makedoniâ (1878-1894) w: Izsledvaniâ po makedonskiâ v"pros, kn. p"rva, Sofiâ 1993, s.314-349; . G. Zbuchea, op.cit. s.26.
} 
Wreszcie nie bez wpływu na płynność zakresu roszczeń pod adresem Bułgarii pozostawały także różnice stanowisk, przedstawianych publicznie w kraju i za granicą przez prominentne osobistości establishmentu rumuńskiego. Celowały one w sztuce operowania środkami wyrafinowanej dyplomacji, za pomocą których manipulowały zręcznie różnymi wariantami swych roszczeń, usiłując dostosować ich treść do wymogów istniejącej w danym momencie koniunktury i dzięki temu uczynić łatwiejszymi do zaakceptowania przez mocarstwa ${ }^{10}$.

Ostateczny etap walki Bukaresztu o Dobrudżę Południową został rozegrany w dobie wojen bałkańskich. I wojna bałkańska, rozpoczęta w październiku 1912 r. atakiem sprzymierzonych państw: Serbii, Bułgarii, Czarnogóry i Grecji na Turcję, była prowadzona $\mathrm{w}$ imię wyzwolenia chrześcijańskiej ludności spod kilkuwiekowej niewoli osmańskiej. W rzeczywistości jednak sojusznicy dążyli do wywalczenia dla siebie jak największych części spuścizny imperium tureckiego na Bałkanach, co nie mogło nie generować ich wzajemnych ostrych sprzeczności. W ocenie rumuńskich kół rządzących nadszedł wówczas odpowiedni czas także dla urzeczywistnienia aspiracji terytorialnych Rumunii. Choć nie brała ona udziału w walkach zbrojnych owego konfliktu, to jednak stanowczo pretendowała do profitów z podziału schedy osmańskiej w Europie.

Tymczasem Bukareszt, pytany przez sojuszników w początkach I wojny bałkańskiej o zachowanie Rumunii w tym konflikcie, udzielał odpowiedzi wymijających. Najwidoczniej preferowano zajęcie pozycji wyczekującej na rozwój wydarzeń zarówno w wymiarze regionalnym, jak i europejskim. Wszelako, nie deklarując formalnie neutralności w wojnie, rząd rumuński powiadomił władze w Sofii, że w zamian za swą faktyczną bezstronność Rumunia po zakończeniu konfliktu przedstawi Bułgarii swoje żądania. Powściągliwość Bukaresztu w określeniu zakresu tych roszczeń wynikała z potrzeby uprzedniego uzyskania dlań aprobaty mocarstw. Nie wydawało się to trudne do osiagnięcia, ponieważ wybuch wojny na Bałkanach podniósł wartość Rumunii, jako sojusznika dwóch rywalizujących ze sobą bloków polityczno-militarnych. Wprawdzie od 1883 r. państwo rumuńskie związane było z Trójprzymierzem, ale w dobie wojen bałkańskich o zbliżenie z Rumunią zabiegała też Rosja, sprzymierzona z Ententą. W rezultacie, po dziesięcioleciach chłodnych stosunków rosyjsko-rumuńskich, rozpoczął się proces ich polepszenia. Znalazło to wyraz $\mathrm{m}$. in. w naleganiu dyplomacji rosyjskiej na rząd bułgarski, aby przystapił do negocjacji z władzami w Bukareszcie w celu rektyfikacji granicy dobrudżańskiej. W tej sytuacji, w obawie przed rezygnacją z sojuszu z Trójprzymierzem i przyłączeniem się Rumunii do Ententy, również Niemcy i Austro-Węgry zaakceptowały rumuńskie pretensje wobec Bułgarii ${ }^{11}$.

W listopadzie 1912 r. rumuńska dyplomacja już konkretnie sformułowała swe żądania, domagając się przesunięcia granicy z Bułgarią na południe wzdłuż linii łączącej

\footnotetext{
10 A. Kuzmanova, op.cit. s.12-13.

11 Ibidem, s. 13-14; M. Tanty, op. cit. s. 53-54.
} 
miasta Tutrakan i Bałczik, obejmującego miasto Silistra ${ }^{12}$. Wprawdzie obszar ten był mniejszy od czworokąta Szumen - Ruse - Silistra - Warna, do którego Rumuni pretendowali w przeszłości, niemniej jednak daleko przekraczał wielkość koncesji, które strona bułgarska skłonna była poczynić na rzecz Bukaresztu w odpowiedzi na coraz wyraźniejsze wezwania Sofii do ustępstw, kierowane ze strony mocarstw. Stąd też władze bułgarskie, choć zdecydowanie odrzuciły roszczenia terytorialne Bukaresztu, nazywając je szantażem, to jednak nie mogły sobie pozwolić na ich totalne zignorowanie. Nie mogły tym bardziej, że ze strony rosyjskiej dawano do zrozumienia, iż konwencja wojskowa rosyjsko-bułgarska z 1902 r., gwarantująca integralność terytorialną Bułgarii, na którą głównie liczono w Sofii, traktowana jest przez Petersburg jak już nieważna ${ }^{13}$.

W rezultacie na początku grudnia 1912 r. rząd bułgarski wysłał przedstawiciela w osobie Stojana Danewa. Nie przyniosły one jednak żadnego pozytywnego efektu, ponieważ władze w Sofii były gotowe jedynie do przyznania Kucowołochom w Macedonii autonomii wyznaniowo-kulturalnej. Nie było zgody natomiast na negocjacje w sprawie jakichkolwiek kompensacji terytorialnych ${ }^{14}$.

Tymczasem, po względnie krótkotrwałym rozejmie w I wojnie bałkańskiej, pojawiła się konieczność wznowienia działań wojennych przeciwko Turcji, obciążających głównie armię bułgarską. Dyskontując trudne położenie Bułgarii, przywódcy rumuńscy wystąpili wówczas z ofensywą propagandową, zapowiadając mobilizację i ustanowienie okupacji w Dobrudży Południowej. Nagłaśniano zarazem na płaszczyźnie krajowej i europejskiej konieczność przesunięcia granicy z Bułgarią do linii Tutrakan - Bałczik, lub co najmniej do linii Silistra -Kawarna. Żądania Bukaresztu, niekolidujące $\mathrm{z}$ interesami Wiednia i Petersburga, dzięki intensywnym zabiegom dyplomacji rumuńskiej, coraz aktywniej popierane były przez Austro-Węgry i Rosję. W takim kontekście międzynarodowym czynniki rządzące w Sofii poczuły się zmuszone do ustępstw. Dnia 29 stycznia 1913 r. w Londynie, gdzie prowadzono rozmowy pokojowe z Turcją, podpisano protokół bułgarsko-rumuński, prezentujący punkt widzenia każdej ze stron w kwestiach spornych. Protokół londyński miał stanowić bazę dalszych pertraktacji, prowadzonych również w stolicy Wielkiej Brytanii. Pomimo jednak pewnej ustępliwości strony bułgarskiej, która już była skłonna do przesunięcia granicy w Dobrudży Południowej i odstąpienia Rumunii trzech niewielkich terenów wzdłuż linii granicznej i wybrzeża czarnomorskiego, Bukareszt niezmiennie obstawał przy linii Tutrakan-Bałczik. Kategorycznego stanowiska rumuńskiego nie zmiękczy-

12 J. Rubacha, Bułgarski sen o Bizancjum. Polityka zagraniczna Bułgarii w latach 1878-1913, Warszawa 2004, s. 280-281.

13 G. P. Genov, Političeska i diplomatičeska istoriâ na B"'lgariâ. B"lgarskata v"nšna politika prez Meždus "ûzničeskta vojna, Sofiâ 2005, s. 95; G. Markov, K”'m istoriâ na b'lgaro-rum "nskiâ spor za Užna Dobrudža po vreme na balkanskite voini (1912-191) w: Iz istoriâ na Dobrudža, Trakiâ i Makedoniâ, Sofiâ 1990, s. 41-42.

14 Szerzej: S. Danev, Memoari, Sofiâ 1992. 
ło nawet wyrażenie gotowości Bułgarii do wyburzenia wszystkich fortyfikacji wokół Silistry, aby wzmocnić poczucie bezpieczeństwa Rumunii ${ }^{15}$.

Bezowocność negocjacji prowadzonych przez reprezentantów Bułgarii i Rumunii doprowadziła 31 marca 1913 r. do poddania sporu bułgarsko-rumuńskiego rozstrzygnięciu konferencji ambasadorów mocarstw w Petersburgu. Podczas kilku posiedzeń ambasadorowie państw Trójprzymierza podtrzymywali maksymalne żądania Rumunii, przedstawiciele mocarstw Ententy zaś optowali za wariantem bardziej umiarkowanym. Ostatecznie 9 maja uzgodniono, że Bułgaria odstapi Rumunom Silistrę wraz z okolicami w promieniu $3 \mathrm{~km}$, licząc od peryferii tego miasta ${ }^{16}$. Decyzja ta jednak nie zaspokoiła apetytu ani czynników rządzących, ani opozycji w Rumunii. W rezultacie w Bukareszcie nie traktowano protokołu petersburskiego jak definitywnej rektyfikacji granicy z Bułgarią, upatrując szansę na przyłączenie żądanego czworokąta w Dobrudży Południowej w zaostrzających się konfliktach pomiędzy dotychczasowymi sojusznikami: Bułgarią i Serbią oraz Bułgarią i Grecją ${ }^{17}$. W dniu 11 czerwca 1913 r. premier rządu rumuńskiego, Titu Maiorescu powiadomił bułgarskiego ambasadora w Bukareszcie, G. Kalinkowa, że w razie wojny Bułgarii z jej byłymi sojusznikami Rumunia ogłosi mobilizację. Wstrzymał się on jednak przed oświadczeniem, po której stronie państwo rumuńskie stanie ${ }^{1818}$.

W międzyczasie wzrastała wartość Rumunii na arenie międzynarodowej jako przyszłego sojusznika jednego z dwóch przeciwstawnych bloków mocarstw europejskich. Z pełną świadomością tego stanu rzeczy dyplomacja rumuńska wyczekiwała najbardziej dogodnego momentu, aby w toku interwencji wojskowej zrealizować maksymalny wariant swych roszczeń. Ten sposobny czas nadszedł, gdy w nocy z 29 na 30 czerwca doszło do bułgarskiego ataku na Serbię i Grecję, zapoczątkowującego II wojnę bałkańską. Kilka dni później, dysponując poparciem mocarstw oraz porozumieniem ze sztabami generalnymi Serbii i Grecji, rząd rumuński zdecydował się na ogłoszenie pełnej mobilizacji. Skoncentrowane wojska przy granicy z Bułgarią miały po sforsowaniu Dunaju ruszyć w dwóch głównych strategicznych kierunkach: ku Dobrudży Południowej i ku zachodowi w stronę miast bułgarskich Swisztow i Orjahowo, a następnie, po podziale tych wojsk na dwie kolumny jedną z nich skierowano na Mihajłowgrad, celem wsparcia sił zbrojnych Serbii, drugą zaś ku Sofii.

11 lipca, w punkcie kulminacyjnym działań zbrojnych armii bułgarskiej przeciwko wojskom serbskim, czarnogórskim i greckim, oddziały rumuńskie zajęły Dobrudżę Południową. Równocześnie armia rumuńska posuwała się w głąb państwa bułgarskiego, zbliżając się do jego stolicy. Warto podkreślić, że Bułgarzy nie stawiali wojskom rumuńskim prawie żadnego oporu; można stwierdzić, że był to niemalże bezkrwawy pochód sił zbrojnych obcego państwa. Niemniej stworzył on nader dogodną sytu-

${ }^{15}$ P. G. Genov, op. cit. s. 89.

${ }^{16}$ G. Markov, op. cit. s. 87 i nn.

17 Ibidem s. 91.

18 P. G. Genov, op. cit. s.15-16, 89; szerzej: G. Kalinkov, Rum "niâ i nejnata politika sprâmo B "lgariâ (1911-1913), Sofiâ 1917. 
ację dla Turcji, której włączenie się do wojny międzysojuszniczej na terytorium Tracji Wschodniej spowodowało osaczenie Bułgarii ${ }^{19}$.

10 lipca rumuński ambasador w Sofii, D. Gika wręczył władzom bułgarskim notę informującą o podjęciu decyzji o inwazji na ich kraj. Kuriozalne było uzasadnienie tego kroku: potrzebę wkroczenia armii rumuńskiej do Bułgarii motywowano faktem, że byli sojusznicy bałkańscy są w stanie wojny i dlatego Rumunia musi bronić równowagi na Bałkanach ${ }^{20}$. Wypowiedzenie wojny przez rząd rumuński zaskoczyło czynniki rządzące w Sofii, które do tej pory zdawały się nie doceniać zagrożenia ze strony północnego sąsiada. Naiwnie wierzono, że Rosja może powstrzymać Rumunów przed atakiem militarnym na państwo bułgarskie. Lecz władze rosyjskie nie zamierzały interweniować w Bukareszcie w interesie Bułgarii, którą ówcześnie postrzegano w Petersburgu nie tylko jak przeciwnika wiernej Serbii, ale również potencjalnego sojusznika Austro-Węgier ${ }^{21}$. W całej pełni ujawnione niepowodzenie prorosyjskiej polityki premiera Danewa doprowadziło do upadku jego gabinetu i utworzenia w Bułgarii nowego rządu na czele z Wasylem Radosławowem ${ }^{22}$.

Wobec perspektywy oczywistej klęski armii bułgarskiej na wszystkich frontach, braku szans na pomoc ze strony mocarstw oraz bezskutecznych propozycji zawieszenia broni, składanych stronom greckiej i serbskiej, czynniki rządzące w Sofii poczuły się zmuszone do zakomunikowania rządowi rumuńskiemu gotowości odstąpienia obszaru Dobrudży Południowej do żądanej przez Bukareszt linii Tutrakan-Bałczik. Ponadto zwrócono się z prośbą o wycofanie wojsk rumuńskich z ziem bułgarskich poza Dunaj. Wszakże Rumuni nie wstrzymali swej ofensywy, traktując ją jako dodatkowy środek nacisku na zabiegających o rozejm Bułgarów. 21 lipca premier Maiorescu wystosował ultymatywny w tonie telegram do nowego ministra spraw zagranicznych Bułgarii, N. Genadiewa, w którym wyrażał zgodę na rozmowy pokojowe podkreślając zarazem, że uważa za bezsporne przyłączenie maksymalnego obszaru Dobrudży Południowej do terytorium swego kraju. Oprócz tego strona rumuńska zażądała usunięcia przez Bułgarów wszelkich fortyfikacji wokół pobliskich miast Ruse i Szumen oraz rezygnacji z budowania nowych twierdz w tej przestrzeni. Domagano się również autonomii kulturalno-religijnej dla ludności wołoskiej, zamieszkującej w granicach państwa bułgarskiego. Jednocześnie depesza narzucała Bułgarii miejsce konferencji pokojowej w Bukareszcie ${ }^{23}$.

26 lipca bułgarska delegacja przybyła do stolicy Rumunii z pełną świadomością, że utrata Dobrudży Południowej została już definitywnie przesądzona. Dziewięć dni później podpisano protokół dotyczący ustanowienia granicy rumuńsko bułgarskiej zgodnie z żądaniami Rumunów, a 10 sierpnia - traktat pokojowy pomiędzy Bułgarią z jednej strony, a Serbią, Czarnogórą, Grecją i Rumunią z drugiej. Odcięcie prowincji

${ }^{19}$ M. Dymarski, Konflikty na Bałkanach w okresie ksztaltowania się państw narodowych $w$ XIX i na poczatku XXw., Wrocław 2010, s. 282-288.

${ }^{20}$ Centralen d"ržaven istoričeski arhiv, f. 176 , op.2, a.e. 1371, 1.150-151.

${ }^{21}$ P.G. Genov, op. cit. s.117 I nn.

${ }^{22}$ Szerzej: P. Kiškilova, B "lgariâ 1913. Krizata v"v vlastta, Sofiâ 1998.

${ }^{23}$ P. G. Genov, op. cit. s. 148-149. 
południowodobrudżanskiej stanowiło dla państwa bułgarskiego jedną z najbardziej dotkliwych klauzul traktatu bukareszteńskiego: zostało ono pozbawione swego cennego spichlerza o powierzchni ok. $7700 \mathrm{~km}^{2}$, zamieszkanego przez ok. 300 tys. mieszkańców, w zdecydowanej większości Bułgarów ${ }^{24}$.

Konkludując warto zauważyć, że kwestia Dobrudży Południowej odgrywała istotną rolę nie tylko w dwustronnych stosunkach Bułgarii i Rumunii, ale także w szerszym wymiarze rywalizacji państw bałkańskich o dominującą pozycję polityczno-strategiczną w regionie.

\title{
ROMANIAN CLAIMS AGAINST BULGARIA DURING THE PERIOD OF THE BALKAN WARS
}

\begin{abstract}
Summary
This paper is to demonstrate the genesis and repercussions of the Romanian territorial claims against Bulgaria during the war period of the 1912-1913 in the Balkan Peninsula. What is most stressed is the direct relationship of the said claims with the separation of Bessarabia from the Romanian state, executed by the 1878 Berlin truce and annexation of Northern Dobruja, a region inhabited mostly by Bulgarians. This last fact inspired the anxiety in Bucharest, that Bulgaria might claim that land by force. This was worsened after 1908, when Bulgaria proclaimed itself a sovereign empire, intent on incorporating major parts of Macedonia and Thrace since the decisive victory over the Ottoman Turkey. Such broadening of the Bulgarian borders was regarded in Bucharest as a threat to the political equilibrium in the Balkans, endangering the Romanian state security and territorial integrity. As a result the government of Romania issued a claim to reestablish the border with Bulgaria, which was in essence a claim over Southern Dobrudja. In spite of rather favorable international circumstances in the early XX century, the Romanians were unable to bring this notion into being until the second half of 1913, the outbreak of an inter-alliance war, a result of frictions between Bulgaria, Serbia and Greece. The lack of success on the side of the Bulgarian armed forces at the western front and the fact that their northern and northeastern provinces were left unprotected incited Romania to invade Bulgaria and annex the Southern Dobrudja. A Turkish invasion followed shortly. As a consequence, and with recognition of the European superpowers of the time, on $10^{\text {th }}$ August 1913 in Bucharest a harsh treaty was imposed on Bulgarians, with the loss of the contested Southern Dobrudja amongst other terms.
\end{abstract}

${ }^{24}$ K. Mančev, V. Bistricki, B"lgarija i neinite s”sedi 1931-1939, Sofiâ 1978, s.18-21. 
